\title{
Intestinal Mucosa of Celiacs in Remission Is Unable To Abolish Toxicity of Gliadin Peptides on in Vitro Developing Fetal Rat Intestine And Cultured Atrophic Celiac Mucosa
}

\author{
H. J. CORNELL, R. S. AURICCHIO, G. DE RITIS, M. DE VINCENZI, L. MAIURI, V. RAIA, AND \\ V. SILANO
}

Department of Applied Chemistry, Royal Melbourne Institute of Technology, Melbourne, Australia [H.J.C.]; Clinica Pediatrica II Facolta' di Medicina e Chirurgia, Naples, Gruppo di Ricerca del Consiglio Nazionale delle Richerche sulla Fisiologia e Patologia dell'Apparato Digerente [S.A., G.d.R., L.M., V.R.]; and Department of Comparative Toxicology and Ecotoxicology, Istituto Superiore di Sanita', Roma, Programme of Preventive Medicine, Project of Perinatal Pathologies and Their Consequences, Consiglio Nazionale delle Richerche, Rome, Italy [M.D.V., V.S.]

\begin{abstract}
Subfraction 2R of fraction 9 from a peptictryptic-pancreatic digest of wheat gliadin is known to be toxic in vivo to celiac patients. We have found that fractions 9 and $2 \mathrm{R}$ inhibit the in vitro development of fetal rat intestine and the increase of enterocyte height occurring in organ culture of atrophic celiac mucosa $(0.1-0.5 \mathrm{mg} / \mathrm{ml}$ medium). Other peptide fractions of the gliadin digest are devoid of such in vitro effects. Subfraction $2 R$, after incubation with morphologically normal small intestinal mucosa of celiacs in remission and ultrafiltration, was still very active in both culture systems at low concentration $(0.1 \mathrm{mg} / \mathrm{ml})$; on the contrary, subfraction $2 \mathrm{R}$ was inactivated after incubation with normal mucosa. These results are compatible with the hypothesis that there is a mucosal defect in handling gliadin peptides in celiac disease, and suggest that there is either a primary (or secondary) enzyme deficiency or some other mechanism operating in the intestinal mucosa of celiac patients in remission. (Pediatr Res 24: 233-237, 1988)
\end{abstract}

Abbreviation

PTC, peptic-tryptic-cotazym

The toxicity of wheat in celiac disease results from the gliadin protein fraction (1-6). The ingestion of peptide mixtures obtained from wheat gluten after in vitro sequential digestion with proteolytic enzymes also induced the typical symptoms in patients affected by celiac disease $(7,8)$. Numerous studies have been done using in vitro systems which could identify the toxic peptide(s) and the mechanism(s) of their toxic activity. The organ culture of human small intestinal biopsies has been proposed as an in vitro model of celiac disease $(9,10)$. Jejunal specimens obtained from patients with active enteropathy show morphological and biochemical improvement when cultured in a medium free from gliadin peptides. No improvement occurs when the tissue is cultured in the presence of gliadin peptides (11-21). The in vitro developing fetal rat intestine also has been demonstrated to be a suitable model for the identification of peptides

Received August 10, 1987; accepted April 13, 1988.

Correspondence Prof. Salvatore Auricchio, Via S. Pansini, 5, 80131-Naples, that are toxic in celiac disease. Gliadin and prolamin peptides from cereals that are toxic in celiac disease (wheat, rye, barley, and oats) are very active in inhibiting in vitro development and morphogenesis of small intestine from 17-day-old rat fetuses (22, 23).

Cornell and Townley (24) fractionated a peptic-tryptic-pancreatic digest of gliadin into 10 primary fractions by chromatography on S.P. Sephadex. Fraction 9 of this digest is the most active in causing significant reduction in D-xylose absorption in celiac patients in remission (25), preventing the morphological recovery of the epithelium of the atrophic intestinal mucosa of celiac patients (26) and inhibiting the in vitro development and differentiation of the fetal rat intestine (22).

Subfractions 1 and 2, obtained by QAE Sephadex chromatography of fraction 9 , and the purified forms 9-1B and 9-2B also have been shown to decrease the urinary excretion of xylose when fed to celiac patients in remission (27). Fraction 9 and subfractions 1 and 2 also were the only ones that were incompletely digested by histologically normal celiac mucosa and by mucosa of first degree relatives of celiac patients when compared to digestion by mucosa of normal controls $(24,27,28)$, suggesting a primary mucosal defect in celiac disease (28).

The aim of our study was to evaluate the capability of the peptide fractions 9 and (subfraction) $2 \mathrm{R}$ to inhibit the in vitro development of the fetal rat intestine and the morphological recovery of cultured atrophic celiac mucosa before and after normal digestion of the fractions with recovered celiac mucosa and normal mucosa.

\section{MATERIALS AND METHODS}

Preparation of gliadin peptides. Gliadin (BDH, U.K.), prepared from the wheat variety "Capella Desprez," was used for the preparation of the digests. PTC digests were prepared by treatment of the gliadin with each of the enzymes in succession and the final digests adjusted to $\mathrm{pH} 3.1$ and centrifuged as described previously by Cornell and Townley (24). The PTC digests were fractionated on S.P. Sephadex (C-25) into 10 major peptide fractions as previously described (24). Subfractions of fraction 9 were prepared on QAE Sephadex A-25 as described previously $(24,28)$. Briefly, this involved the application of fraction $9(400 \mathrm{mg})$ to a column $(23 \times 1.4 \mathrm{~cm})$ of QAE Sephadex equilibrated in $0.02 \mathrm{M}$ Tris-citrate buffer, $\mathrm{pH}$ 9.2. Subfraction 1 was eluted in the starting buffer and subfraction 2 was then 
eluted on application of a $0.02 \mathrm{M}$ Tris-citrate buffer of $\mathrm{pH} 6.0$. The lyophilized subfraction 2 was desalted on Biogel P-2 (BioRad Laboratories, Richmond, CA) and again lyophilized. The major components of these subfractions have an apparent mol. wt. of 1400-1500 (28).

Subfraction 2 of fraction 9 was incubated with remission celiac mucosa at $37^{\circ} \mathrm{C}$ and $\mathrm{pH} 7.5$ for $2 \mathrm{~h}$ after which it was heated to $60^{\circ} \mathrm{C}$ for $5 \mathrm{~min}$ and ultrafiltered using "Centriflo" CF 50 membrane cones (Amicon Corp., Redwood City, CA) as reported previously (24). The concentration of the peptides and amino acids remaining after digestion were measured by the microKjeldahl method.

In vitro culture of fetal rat intestine. Pregnant Wistar rats were anesthetized with ether and 17-day-old fetuses were removed at laparotomy. Fetal jejunum segments were isolated and cultured in vitro for $48 \mathrm{~h}$ in a serum-free medium according to the method described by de Ritis et al. (29). Jejunal segments from the same fetus were cultured in the absence and presence of the peptides. All the peptide mixtures were sterilized before addition to incubation medium by filtration through $0.22 \mathrm{~m} \mu$ Millipore filters. Differentiation of the fetal rat jejunum was followed morphologically by light microscopy as reported by de Ritis et al. (29) without knowledge of the culture conditions.

A morphological assessment of histological changes during organ culture of 17-day-old fetus intestine was performed on the more external part of the tissue where the epithelium more clearly showed developmental changes in the absence of gliadin peptides. In this part of the tissue specimen we constantly observed wellformed villi that do not develop in the more internal part of the intestinal segment probably as the consequence of the more difficult penetration of the tissue by the culture medium. The first five sections were cut off and the next 10-20 sections were evaluated. No appreciable variations in the developmental pattern of intestinal mucosa were observed among these histological sections.

In vitro culture of human small intestinal mucosa. Intestinal biopsies were obtained at the duodenojejunal flexure from 11 children affected by active celiac disease with subtotal mucosal atrophy. Diagnosis of celiac disease was based on the presence of clinical malabsorption and typical histological lesions of intestinal mucosa, both of which healed after several months on a gluten-free diet. The small intestinal lesions relapsed after introduction of gluten into the diet.

The tissue was cultured for $30 \mathrm{~h}$ in a serum-containing medium, without and with added peptide fractions, according to the method of Browning and Trier (30) as modified by Jos et al. (14). Just after their excision and after $30 \mathrm{~h}$ in culture, biopsy specimens were fixed in $10 \%$ formol, dehydrated, embedded in paraffin, and serially sectioned. Changes in enterocyte height during culture were used as a marker of toxicity. These were measured according to Howdle et al. (20) without knowledge of the culture conditions. At least 20 enterocytes were measured in each section and the mean enterocyte height was calculated for each section.

\section{RESULTS}

In vitro culture of fetal rat intestine. Before culture, the jejunal mucosa of 17-day-old fetuses showed only undifferentiated cuboidal stratified epithelial cells lining the lumen; there were no villi. No goblet cells could be detected in any of the uncultured fetuses (Table 1; Fig $1 A$ ). After $48 \mathrm{~h}$ of in vitro culture in the absence of gliadin peptides (Table 1; Fig. $1 B$ ), well-formed villi were present in 17 fetal jejunum segments and rudimentary villi were observed in jejunal segments from only one fetus.

In all cultured segments the epithelial lining consisted exclusively of simple columnar epithelium and in seven cases goblet cells were detected. Patchy, slight degenerative changes were observed only in a few cultured jejuna from five fetuses. These results confirm previous results by de Ritis et al. (29) showing that differentiation and maturation of small intestinal mucosa from rat fetus take place in vitro in a way comparable to in vivo differentiation.Fractions 1 and 5 did not affect in vitro differentiation of fetal rat jejunum, even when tested at a concentration as high as $0.5 \mathrm{mg} / \mathrm{ml}$. At this concentration, fraction 9 and subfraction $2 \mathrm{R}$ were able to inhibit in vitro development of fetal rat intestine and to increase occurrence and severity of degener-

Table 1. Effect of various fractions from a peptic-tryptic-pancreatic digest of wheat gliadin on in vitro developing fetal rat intestine

\begin{tabular}{|c|c|c|c|c|c|c|c|c|c|c|c|}
\hline \multirow[b]{3}{*}{ Sample* } & & & \multicolumn{3}{|c|}{ Villi } & \multicolumn{3}{|c|}{ Epithelium } & \multirow{3}{*}{$\begin{array}{l}\text { Goblet } \\
\text { cells }\end{array}$} & \multicolumn{2}{|c|}{$\begin{array}{c}\text { Degenerative } \\
\text { changest }\end{array}$} \\
\hline & & & \multirow[b]{2}{*}{ Absent } & \multirow[b]{2}{*}{ Rudimentary } & \multirow[b]{2}{*}{ Present } & \multirow[b]{2}{*}{ Stratified } & \multicolumn{2}{|c|}{ Monostratified } & & \multirow[b]{2}{*}{ \pm} & \multirow[b]{2}{*}{++} \\
\hline & & & & & & & Cuboidal & Columnar & & & \\
\hline Uncultured 17-day-old fetuses & & (18) & 18 & & & 18 & & & & & \\
\hline \multicolumn{12}{|l|}{ After $48 \mathrm{~h}$ culture: } \\
\hline a) Without peptides & & (18) & & 1 & 17 & & & 18 & 7 & 5 & \\
\hline$\ddagger$ b) Fraction $9 \S$ & $0.5 \mathrm{mg} / \mathrm{ml}$ & (3) & 3 & & & & & & & & 3 \\
\hline c) Fraction $9 \S$ & $0.2 \mathrm{mg} / \mathrm{ml}$ & (4) & 4 & & & & 2 & 2 & & 1 & 3 \\
\hline d) Fraction $9 \S$ & $0.1 \mathrm{mg} / \mathrm{ml}$ & (3) & 1 & 2 & & & & 3 & & 3 & \\
\hline e) Fraction $2 R$ & $0.5 \mathrm{mg} / \mathrm{ml}$ & (7) & 7 & & & & 1 & 6 & & 3 & 2 \\
\hline f) Fraction $2 R$ & $0.2 \mathrm{mg} / \mathrm{ml}$ & (4) & 3 & 1 & & & & 4 & & 1 & 1 \\
\hline g) Fraction $2 R$ & $0.1 \mathrm{mg} / \mathrm{ml}$ & (6) & 1 & 5 & & & 2 & 4 & & 1 & 2 \\
\hline$\|$ h) Fraction 2R CDI & $0.5 \mathrm{mg} / \mathrm{ml}$ & (2) & 2 & & & & & 2 & & 1 & 1 \\
\hline$\|$ i) Fraction $2 \mathrm{R} \mathrm{ND**, \dagger \dagger}$ & $0.5 \mathrm{mg} / \mathrm{ml}$ & (2) & & 1 & 1 & & & 2 & & & \\
\hline || 1) Fraction 2R CDI & $0.1 \mathrm{mg} / \mathrm{ml}$ & (8) & 6 & 2 & & & 2 & 6 & & 5 & 2 \\
\hline$\| \mathrm{m})$ Fraction $2 \mathrm{R} \mathrm{ND}^{* *}+\dagger$ & $0.1 \mathrm{mg} / \mathrm{ml}$ & (7) & & 1 & 6 & & & 7 & 3 & 1 & \\
\hline
\end{tabular}

* No. of fetuses examined or of fetal jejuna cultured in parentheses.

$\dagger \pm$, slight degenerative changes; ++ , large necrotic areas.

$\ddagger$ Epithelium poor recognizable.

$\S$ Difference from the value before culture, $p=1.44 \times 10^{-5}$.

$\| \mathrm{CD}$, celiac digest. ND, normal digest. Frequency distribution analysis by Fisher's exact test. The two groups rudimentary and present are pooled for the analysis. The results obtained at various concentrations of gliadin peptides are grouped together for analysis.

I Difference from the value before culture, $p=1.44 \times 10^{-5}$.

*** Difference from the value after culture with fraction $2 \mathrm{R} \mathrm{CD}, p=5.9 \times 10^{-4}$.

$\dagger+$ Difference from the value before culture, $p=0.99$. 

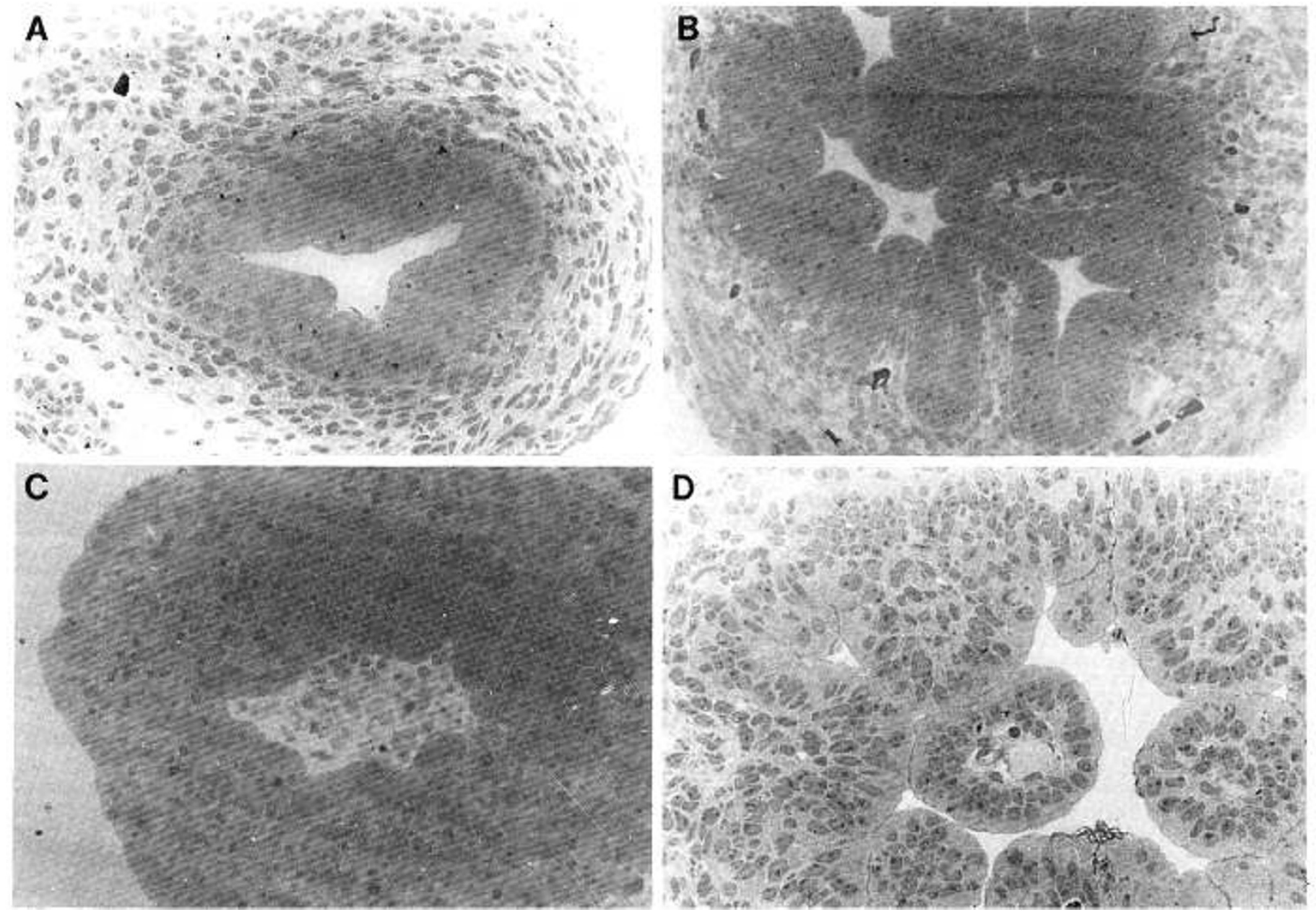

Fig. 1. Effect of subfraction $2 \mathrm{R}$ after digestion by histologically normal celiac mucosa and normal mucosa from controls on in vitro development and morphogenesis of jejunum from 17-day-old rat fetus. $A$, jejunal mucosa before culture. The epithelium consists of stratified undifferentiated cells and no villi are present. $B$, jejunal mucosa after $48 \mathrm{~h}$ of culture. $C$, jejunal mucosa after $48 \mathrm{~h}$ culture in the presence of subfraction $2 \mathrm{R}$ after digestion by histologically normal celiac mucosa $(0.1 \mathrm{mg} / \mathrm{ml})$. No villi developed on the mucosal surface which is lined by cuboidal and a few columnar epithelial cells. Degenerative changes are present. $D$, jejunal mucosa after $48 \mathrm{~h}$ culture in the presence of the subfraction $2 \mathrm{R}$ after digestion by histologically normal mucosa from normal controls $(0.1 \mathrm{mg} / \mathrm{ml})$ : differentiation of fetal rat intestinal mucosa occurs with appearance of welldeveloped villi. The epithelium consists of a single layer of relatively differentiated cells.

Table 2. Enterocyte ht $(\mu)$ before and after $30 \mathrm{~h}$ culture with $(+)$ and without $(-)$ fraction $2 R$ peptides; tissue from celiac patients with subtotal mucosal atrophy

\begin{tabular}{|c|c|c|c|c|c|c|c|c|c|c|c|c|c|c|}
\hline \multirow[b]{2}{*}{$\begin{array}{c}\text { Case } \\
\text { no. }\end{array}$} & \multicolumn{4}{|c|}{ Fraction $2 \mathrm{R}$} & \multirow[b]{2}{*}{$\begin{array}{c}\text { Case } \\
\text { no. }\end{array}$} & \multicolumn{4}{|c|}{ Fraction $2 \mathrm{R}$ celiac digest } & \multirow[b]{2}{*}{$\begin{array}{l}\text { Case } \\
\text { no. }\end{array}$} & \multicolumn{4}{|c|}{ Fraction $2 \mathrm{R}$ normal digest } \\
\hline & $\begin{array}{l}\text { Concentration } \\
(\mathrm{mg} / \mathrm{ml})\end{array}$ & $0 \mathrm{~h}$ & $\begin{array}{l}30 \mathrm{~h} \\
(-)\end{array}$ & $\begin{array}{l}30 \mathrm{~h} \\
( \pm)\end{array}$ & & $\begin{array}{l}\text { Concentration } \\
(\mathrm{mg} / \mathrm{ml})\end{array}$ & $0 \mathrm{~h}$ & $\begin{array}{c}30 \mathrm{~h} \\
(-)\end{array}$ & $\begin{array}{c}30 \mathrm{~h} \\
(+)\end{array}$ & & $\begin{array}{c}\text { Concentration } \\
(\mathrm{mg} / \mathrm{ml})\end{array}$ & $0 \mathrm{~h}$ & $30(-)$ & $\begin{array}{c}30 \mathrm{~h} \\
(+)\end{array}$ \\
\hline 1 & 0.5 & 18.8 & 22.8 & 18.7 & 3 & 0.1 & 18.7 & 21.8 & 15.2 & 7 & 0.1 & 19.3 & 23.0 & 24.0 \\
\hline \multirow[t]{4}{*}{ 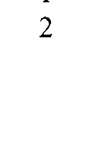 } & 0.5 & 19.3 & 23.4 & 19.0 & 4 & 0.1 & 18.0 & 23.2 & 13.5 & 8 & 0.1 & 19.0 & 21.8 & 21.7 \\
\hline & & & & & 5 & 0.1 & 18.0 & 22.8 & 13.5 & 9 & 0.1 & 19.3 & 22.0 & 21.8 \\
\hline & & & & & 6 & 0.1 & 17.0 & 20.6 & 14.0 & 10 & 0.1 & 18.0 & 22.4 & 22.8 \\
\hline & & & & & & & & & & 11 & 0.1 & 19.2 & 24.1 & 23.4 \\
\hline Mean & & 19.05 & $23.1^{*}$ & 18.85 & Mean & & 17.92 & $22.1^{*}$ & 14.05 & Mean & & 18.97 & $22.66 \dagger$ & 22.74 \\
\hline$\pm \mathrm{SD}$ & & \pm 0.3 & \pm 0.4 & \pm 0.2 & $\pm \mathrm{SD}$ & & \pm 0.69 & \pm 1.16 & \pm 0.8 & $\pm \mathrm{SD}$ & & \pm 0.55 & \pm 0.92 & \pm 0.99 \\
\hline
\end{tabular}

* Difference from the value before culture and after culture with the fraction, $p<0.01$ (paired $t$ test).

$\dagger$ Difference from the value before culture $p<0.01$. Difference between the values after culture $p>0.05$ (paired $t$ test).

ative changes (Table 1). Such effects were clearly observed at a concentration as low as $0.1 \mathrm{mg} / \mathrm{ml}$.

Subfraction $2 \mathrm{R}$ after digestion by intestine from patients affected by celiac disease remains very active in slowing down in vitro development of fetal rat intestine and in increasing the prevalence and severity of degenerative changes, whereas the toxicity of the same fraction after digestion by the intestine of normal subjects is absent or almost absent even at the highest tested concentration $(0.5 \mathrm{mg} / \mathrm{ml})$. Well-differentiated villi were absent in six of eight cultures and were rudimentary in the remaining two cultures in the presence of $0.1 \mathrm{mg} / \mathrm{ml}$ of $2 \mathrm{R}$ after celiac digestion (Table 1; Fig. 1C); villi were, on the contrary, well developed in six of seven cultures in the presence of the same quantity of $2 \mathrm{R}$ after normal digestion, and goblet cells were present in three cultures (Table 1; Fig. $1 D$ ).

In vitro culture of human small intestinal mucosa. Before in 

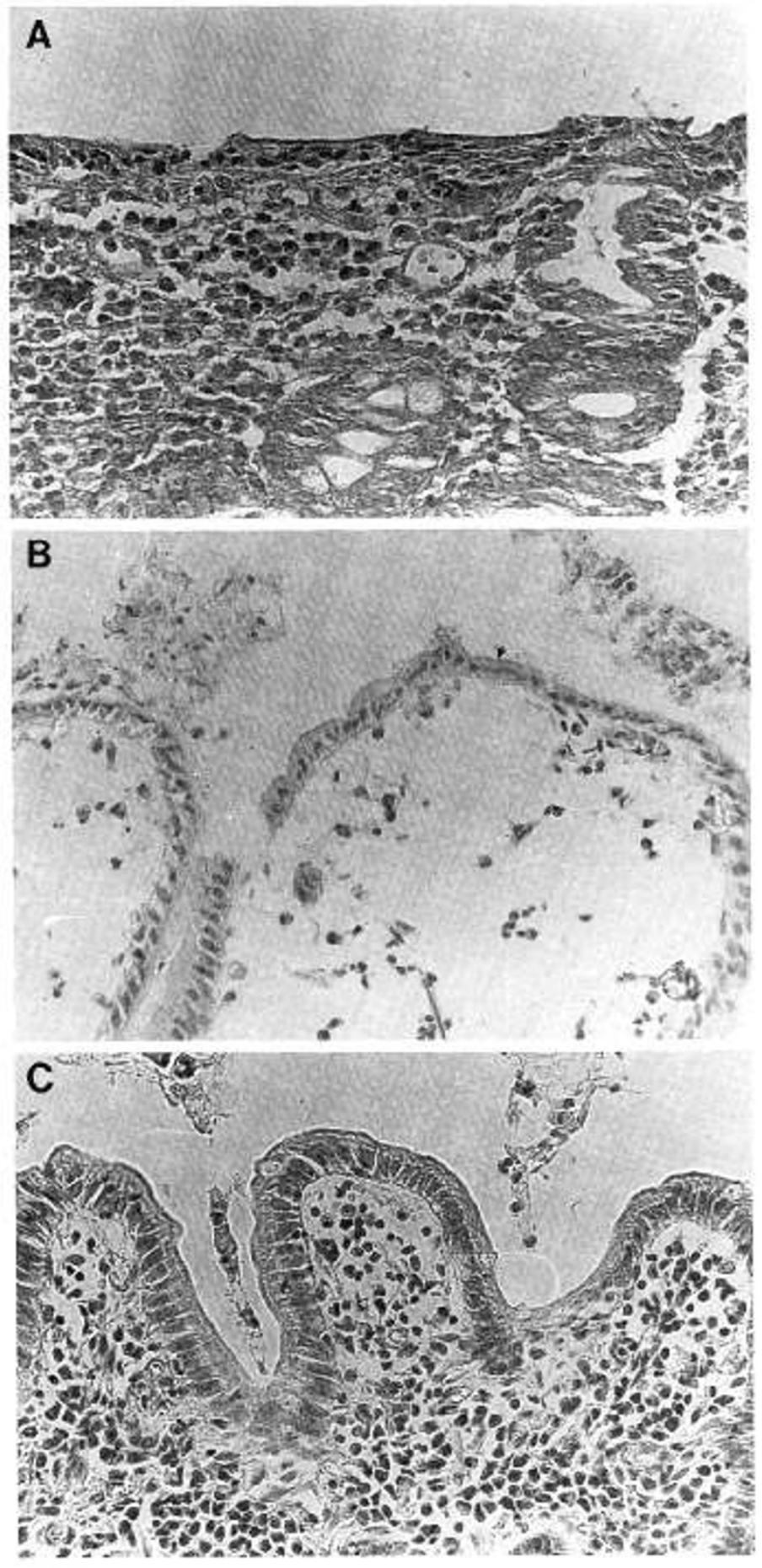

Fig. 2. Effect of the subfraction $2 R$ after digestion by histologically normal celiac mucosa and normal mucosa from controls on in vitro culture of jejunal biopsy specimens from children with untreated celiac disease. $A$, jejunal mucosa before culture. A total loss of villous pattern with cuboidal and irregular epithelial cells is evident. $B$, jejunal mucosa after $30 \mathrm{~h}$ of culture in the presence of subfraction $2 \mathrm{R}$ after digestion by histologically normal celiac mucosa $(0.1 \mathrm{mg} / \mathrm{ml})$. The tissue does not show any improvement. The surface epithelium is damaged and degenerative changes are evident. $C$, jejunal mucosa after $30 \mathrm{~h}$ of culture in the presence of subfraction $2 \mathrm{R}$ after digestion by histologically normal mucosa from normal controls $(0.1 \mathrm{mg} / \mathrm{ml})$. The morphological abnormalities of the surface epithelium have almost completely disappeared showing recovery of the surface epithelium cells that are taller and more regular. vitro culture all the small intestinal biopsy specimens from children with active celiac disease showed a flat mucosa with total loss of villous pattern and with elongated hypertrophic crypts. The surface epithelium showed cuboidal cells with irregular nuclei, and the enterocyte height was decreased (Table 2; Fig. $2 A$ ). After $30 \mathrm{~h}$ culture in the absence of gliadin peptides all these biopsies showed significant recovery; the enterocyte was taller with basically oriented nuclei. Biopsy specimens did not recover when cultured in the presence of subfraction $2 \mathrm{R}(0.1$ $\mathrm{mg} / \mathrm{ml}$ ) before and after incubation with celiac mucosa, whereas the same subfraction after incubation with normal mucosa $(0.1$ $\mathrm{mg} / \mathrm{ml}$ ) did not inhibit epithelial recovery occurring after $30 \mathrm{~h}$ culture (Table 2; Fig. $2 B$ and $C$ ).

\section{DISCUSSION}

In our study we have demonstrated that fraction 9 and its subfraction $2 \mathrm{R}$, obtained from a peptic-tryptic-pancreatic digest of bread wheat gliadin are very active in inhibiting in vitro development of fetal rat intestine. Subfraction $2 \mathrm{R}$ also is able to prevent in vitro morphological recovery of the enterocytes of atrophic celiac mucosa. The other fractions tested were less active or not active in these in vitro systems. The results therefore confirm previously published findings $(22,24)$. The activity of gliadin peptides in the various in vitro systems we use appears to be in some way related to the in vivo toxicity in celiac disease, as the same fractions 9 and $2 \mathrm{R}$ have been shown to contain a large proportion of gliadin peptides that are toxic in vivo to celiac patients.

Previous studies of Cornell and Rolles (28) have demonstrated that fraction 9 and subfractions $1 R$ and $2 R$ are the only ones that were incompletely digested by remission celiac mucosa when compared to digestion with mucosa from normal controls. The major aim of the present study was to determine whether there is some difference between celiac and control mucosa regarding the ability to detoxify the in vitro and in vivo toxic subfraction $2 \mathrm{R}$. The peptides of subfraction $2 \mathrm{R}$ remaining after digestion with histologically normal celiac mucosa were still able to inhibit the in vitro development of fetal rat intestine and to prevent in vitro recovery of enterocytes of atrophic celiac mucosa, whereas these activities were absent after digestion of the same peptide fraction with normal mucosa.

These results suggest that celiac mucosa is not able to detoxify the gliadin peptide fractions which are toxic for celiac patients and are compatible with the hypothesis that there is some mucosal defect in celiac disease. However, whether these in vitro studies apply to the in vivo situation is unknown. Definitive proof of this hypothesis should be confirmed by further studies. One possible way would be to identify the structure of one (or more) of the in vitro toxic peptides remaining after digestion with celiac mucosa and to obtain large amounts by synthesis of this peptide(s) for further in vivo studies.

The nature of the defect of celiac mucosa in handling in vitro the $2 \mathrm{R}$ gliadin fraction in unknown. This may be due to lack in celiac mucosa of a specific enzyme involved in digestion of these particular gliadin peptides. It has been demonstrated (31) that the pattern of gliadin digestion by normal and celiac mucosa is basically the same, and that the activities of various digestive peptidases are normal or almost normal in histologically normal intestinal mucosa of celiac patients. Nevertheless, the possibility that an enzyme different from those tested up to now is lacking in celiac mucosa is not yet completely disproved. The enzymatic deficiency could be primary or secondary to the celiac disease. The mucosa we used for digestion of subfraction $2 \mathrm{R}$ is histologically within normal limits, and disaccharidase activities were also found to be normal, suggesting that the mucosal defect, if present, could be primary. The possibility also remains that the mucosal defect is secondary, as there will always be doubt whether the tissue has completely recovered or whether the 
gliadin-free diet on which the patients are placed may influence some enzymatic activities of the intestine.

It is known that the activity of the aminopeptidase A (31) remains low in celiac mucosa in remission. The defect of celiac mucosa in handling some gliadin peptides may not be due to an enzyme deficiency. For example, a decreased binding to the celiac mucosa of gliadin peptides as compared with normal mucosa could also explain our results, as we have studied, in the various in vitro systems, only the peptides that are present in the ultrafiltrates of the incubation mixtures.

Acknowledgments. The authors thank Francesco Paparo for technical assistance.

\section{REFERENCES}

1. Auricchio S, De Vizia B, Carta De Angelis L, Silano V 1974 Alpha-amylase protein inhibitors from wheat in coeliac disease Lancet 1:98

2. Dicke WM, Weijers HA, Van De Kamer JH 1953 Presence in the wheat of a factor having a deleterious effect in cases of coeliac disease. Acta Pediatr 42:34-42

3. Van De Kamer JH, Weijers HA, Dicke WM 1953 Investigation into the injurious constituent of wheat in connection with their action on patients with coeliac disease. Acta Pediatr 42:223-231

4. Van De Kamer JH, Weijers HA 1955 Celiac disease: some experiments on cause of harmful effect of wheat gliadin. Acta Pediatr 44:465-469

5. Baker PG, Read AE 1976 Oats and barley toxicity in coeliac patients. Postgrad Med J 52:264-268

6. Kasarda DD 1981 Toxic proteins and peptides in coeliac disease: relation to cereal genetics. In: Walker DN, Kretchmer N (eds) Food Nutrition and Evolution. Masson Publishing, New York, pp 201-216

7. Frazer AC 1956 Discussion on some problems of steathorrea and adult coeliac disease. Proc R Soc Med 49:1009-1013

8. Frazer AC, Fletcher RF, Ross CAC, Shaw B, Sammons HG, Schneider R 1959 Gluten-induced enteropathy. The effect of partially digested gluten. Lancet 2:252-255

9. Falchuk ZM, Gebhard RL, Sessoms C, Strober W 1974 An in vitro model of gluten sensitive enteropathy. J Clin Invest 53:487-500

10. Falchuk ZM, Katz AG 1978 Organ culture model of gluten sensitive enteropathy. In: McNicholl B, McCarthy CF, Fottrell PF (eds) Perspectives in Coeliac Disease. MTP Press Limited, Lancaster, pp 65-73

11. Fluge G, Aksnes L 1978 In vitro assessment of gluten toxicity by organ culture of human duodenal mucosa.In: McNicholl B, McCarthy CF, Fottrell PF (eds) Perspectives in Coeliac Disease. MTP Press Limited, Lancaster, pp 9199

12. Howdle PD, Corazza GR, Bullen AW, Losowsky MS 1979 In vitro demonstration of mucosal sensitivity to gluten. Gut 20:A436(abstr)

13. Jos J, Charbonnier L, Mougenot JF, Mosse J, Rey J 1978 Isolation and characterization of the toxic fraction of wheat gliadin in coeliac disease.In: McNicholl B, McCarthy CF, Fottrell PF (eds) Perspectives in Coeliac Disease. MTP Press Limited, Lancaster, pp 75-90

14. Jos J, Lenoir G, de Ritis G, Rey J 1975 In vitro pathogenetic studies of coeliac disease. Effect of protein on coeliac intestinal biopsy specimens maintained in culture for 48 hours. Scand J Gastroenterol 10:121-128

15. Jos J, Charbonnier L, Mosse J, Olives JP, De Tand MF, Rey J 1982 The toxic fraction of gliadin digest in coeliac disease. Isolation by chromatography on Biogel P-10. Clin Chim Acta 119:263-274

16. Jos J, De Tand MF, Charbonnier L 1980 Use of gel filtration to isolate the toxic fraction of gliadin digest in coeliac disease. Acta Pediatr Bel 33:269274

17. Fluge $G$, Aksnes L 1981 Labelling indices after ${ }^{3} \mathrm{H}$-thymidine incorporation during organ culture of duodenal mucosa in coeliac disease. Scand J Gastroenterol 16:921-928

18. Fluge G, Aksnes L 1981 Morphological and morphometric assessment of human duodenal biopsies maintained in organ culture. Scand J Gastroenterol 16:555-567

19. Fluge G, Andersen KJ, Aksnes L, Thunold K 1982 Brush border and lysosomal marker enzyme profiles in duodenal mucosa of coeliac patients before and after organ culture. Scand J Gastroenterol 17:465-472

20. Howdle PD Corazza GR, Bullen AW, Losowsky MS 1981 Gluten sensitivity of small intestinal mucosa in vitro: quantitative assessment of histologic changes. Gastroenterology 80:442-450

21. De Ritis G, Auricchio S, Jones HW, Lew EJ, Bernardin JE, Kasarda DD In vitro (organ culture) studies of the toxicity of specific A-gliadin peptides in coeliac disease. Gastroenterology (in press)

22. De Ritis G, Occorsio P, Auricchio S, Gramenzi F, Morisi G, Silano V 1979 Toxicity of wheat flour proteins and protein-derived peptides for in vitro developing intestine from rat fetus. Pediatr Res 13:1255-1261

23. Auricchio S, Cardelli M, de Ritis G, De Vincenzi M, Latte F, Silano V 1984 An in vitro animal model for the study of cereal components toxic in coeliac disease. Pediatr Res 18:1372-1378

24. Cornell HJ, Townley RRW 1973 Investigation of possible intestinal peptidase deficiency in coeliac disease. Clin Chim Acta 43:113-125

25. Cornell HJ, Townley RRW 1974 The toxicity of certain cereal proteins in coeliac disease. Gut 15:862-869

26. Townley RRW, Bhathal PS, Cornell HJ, Mitchell JD 1973 Toxicity of wheat gliadin fractions in coeliac disease. Lancet 1:1363-1364

27. Cornell HJ, Maxwell RJ 1982 Amino acid composition of gliadin fractions which may be toxic to individuals with coeliac disease. Clin Chim Acta 123:311-319

28. Cornell HJ, Rolles CJ 1978 Further evidence of a primary mucosal defect in coeliac disease: in vitro mucosal digestion studies in coeliac patients in remission, their relatives, and control subjects. Gut 19:253-259

29. De Ritis G, Falchuk ZM, Trier JS 1982 Differentiation and maturation of cultured fetal rat jejunum. Dev Biol 45:304-317

30. Browning TH, Trier JS 1969 Organ culture of mucosal biopsies of human small intestine. J Clin Invest 40:1423-1432

31. Andria G, Cucchiara S, De Vizia B, Mazzacca G, Auricchio S 1980 Brush border and cytosol peptidase activities of human small intestine in normal subjects and in coeliac patients. Pediatr Res 14:812-818 